
\title{
3 Research Soure \\ Effect of TiC0.4 Addition on Microstructures and Properties of Ti3SiC2 Matrix Composites
}

\author{
Qin Zou \\ Yanshan University \\ Zhichao Lou \\ Yanshan University \\ Junlong Liu \\ Yanshan University \\ YanGuo Li ( $\sim$ lyg@ysu.edu.cn ) \\ Yanshan University \\ Jiangbo Xu \\ Yanshan University \\ Yuanyuan Li \\ Yanshan University \\ Lingyu Bu \\ Yanshan University \\ Peng Wang \\ Yanshan University \\ Yong'an Luo \\ Yanshan University
}

\section{Research Article}

Keywords: Ti3SiC2 matrix composite, TiC0.4, Microstructure, Mechanical properties, Tribology

Posted Date: February 3rd, 2022

DOI: https://doi.org/10.21203/rs.3.rs-1292035/v1

License: (c) (i) This work is licensed under a Creative Commons Attribution 4.0 International License.

Read Full License 


\section{Abstract}

$\mathrm{TiC}_{0.4^{-}}-\mathrm{Ti}_{3} \mathrm{SiC}_{2}$ composites were manufactured using spark plasma sintering (SPS) at $1400^{\circ} \mathrm{C}$ for $10 \mathrm{~min}$, with an applied pressure of $40 \mathrm{MPa}$. The effect of $\mathrm{TiC}_{0.4}$ additions on microstructures and properties of $\mathrm{Ti}_{3} \mathrm{SiC}_{2}$ matrix composites was investigated. The addition of $\mathrm{TiC}_{0.4}$ induced the formation of $\mathrm{TiC}_{\mathrm{x}}$ $(0.4 \unrhd \mathrm{x} \leq 1)$ and promoted the decomposition of $\mathrm{Ti}_{3} \mathrm{SiC}_{2}$, yielding $\mathrm{TiC}_{\mathrm{x}}$ and $\mathrm{Ti}_{5} \mathrm{Si}_{3}$. The mechanical and tribological properties of the $\mathrm{TiC}_{0.4}-\mathrm{Ti}_{3} \mathrm{SiC}_{2}$ composite improved with the $\mathrm{TiC}_{0.4}$ content due to $\mathrm{C}$ vacancy present in $\mathrm{TiC}_{0.4}$, although the friction distance in the initial stage of friction test was increased. The 30 vol.\% $\mathrm{TiC}_{0.4}-\mathrm{Ti}_{3} \mathrm{SiC}_{2}$ composites exhibited the highest hardness and fracture toughness of $14.87 \mathrm{GPa}$ and $5.45 \mathrm{MPa} \cdot \mathrm{m}^{1 / 2}$. At the same conditions, the wear rate at room temperature reached a minimum value of $4.32 \times 10^{-7} \mathrm{~mm}^{3} \mathrm{~N}^{-1} \mathrm{~m}^{-1}$, while the friction coefficient was 0.74 . The friction distance in the initial friction stage of 30 vol. \% $\mathrm{TiC}_{0.4}-\mathrm{Ti}_{3} \mathrm{SiC}_{2}$ was about $38 \mathrm{~m}$, and the wear mechanism of the composite at room temperature was mainly adhesive wear.

\section{Highlights}

1. The effect of $\mathrm{C}$ vacancy in $\mathrm{TiC}_{0.4}$ can not only promote the decomposition of $\mathrm{Ti}_{3} \mathrm{SiC}_{2}$ to form hard phases of $\mathrm{TiC}_{\mathrm{x}}$ and $\mathrm{Ti}_{5} \mathrm{Si}_{3}$, but also improve the interface bonding between $\mathrm{Ti}_{3} \mathrm{SiC}_{2}$ and $\mathrm{TiC}_{\mathrm{x}}$.

2. The addition of $\mathrm{TiC}_{0.4}$ forms the hard phase of $\mathrm{TiC}_{\mathrm{x}}$ and decreases the $\mathrm{Ti}_{3} \mathrm{SiC}_{2}$ grain size.

3. The value of bulk density, relative density, hardness and fracture toughness has the same trend of continuous climbing up with the increase of $\mathrm{TiC}_{0.4}$ adding amount, while that of wear rate exhibits a declining trend. The value of the friction coefficient remains stable initially and then increases.

4. With the increase of $\mathrm{TiC}_{0.4}$ adding amount, the content of $\mathrm{TiC}_{\mathrm{x}}$ particles in the detached particle increases, resulting in the difficulty of forming the complete lubricating film on the friction surface of $\mathrm{TiC}_{0.4}-\mathrm{Ti}_{3} \mathrm{SiC}_{2}$ composite, and then increases the initial friction distance.

5. The integrity of the lubricating film is improved by the pinning effect of $\mathrm{TiC}_{\mathrm{x}}$ particle, resulting in the decrease of friction coefficient and wear rate.

\section{Introduction}

$\mathrm{Ti}_{3} \mathrm{SiC}_{2}$ ternary ceramic embodies the advantages of both ceramics and metals, such as high Young's modulus (343 GPa) [1], high fracture toughness $\left(7.20 \mathrm{MPa} \cdot \mathrm{m}^{1 / 2}\right)$ [2], high corrosion resistance[3], good thermal and electrical conductivity (43 W/m.K and 9.6 $10^{6} \Omega^{-1} \mathrm{~m}^{-1}$ ) [4], thermal shock resistance [5], etc. Its layered crystal structure is comparable to that of well-known graphite and $\mathrm{MoS}_{2}$ solid lubricants, implying that it may be an excellent solid lubricant material with a low friction coefficient [6]. Thus, $\mathrm{Ti}_{3} \mathrm{SiC}_{2}$ could find potential applications in bearings, turbines, cutting tools, electrical contacts, heat exchangers [7-11], etc. However, this is severely hampered by low hardness (4.54 GPa) and wear resistance $\left(0.21-1.87 \times 10^{-3} \mathrm{~mm}^{3} / \mathrm{N} \cdot \mathrm{m}\right)$ of $\mathrm{Ti}_{3} \mathrm{SiC}_{2}$ ceramics [12]. Many reinforcing phases, including 
$\mathrm{Al}_{2} \mathrm{O}_{3}$, SiC, $\mathrm{TiC}^{-\mathrm{TiS}}{ }_{2}$, and $\mathrm{TiC}^{-\mathrm{TiB}_{2}}$, were applied to improve the hardness and wear resistance of $\mathrm{Ti}_{3} \mathrm{SiC}_{2}$ due to the nailing of the softer phase by the hard phase [13-15]. However, we still lack the solution for the weak interfacial bonding between these reinforcing phases and the $\mathrm{Ti}_{3} \mathrm{SiC}_{2}$ matrix, limiting the reinforcing phases' enhancement effect. $\mathrm{TiC}_{0.4}$ is a representative of nonstoichiometric $\mathrm{TiC}_{\mathrm{x}}(0.3<\mathrm{x}<0.9)$ compounds, exhibiting a $\mathrm{NaCl}$-type crystal structure [16-18]. It possesses high hardness (24.1-24.8 GPa), and the existence of vacancies improves the interfacial bonding between the reinforcing phase and the matrix [19-21]. Recently, $\mathrm{TiC}_{\mathrm{x}}$ was used to improve the mechanical properties of the Al or Cu matrix composite, showing that the hardness and bending strength were increased by $84.7-116.3$ and $80.7-122.4 \%$, respectively, compared to the $\mathrm{Al}$ or Cu matrix composite without $\mathrm{TiC}_{\mathrm{x}}[21,22]$.

In this study, we prepared the $\mathrm{TiC}_{0.4}\left(10,20\right.$, and 30 vol.\%) particles-reinforced $\mathrm{Ti}_{3} \mathrm{SiC}_{2}$ matrix composites using SPS. Meanwhile, the effect of TiC0.4 content on the microstructure, mechanical properties, and friction and wear behaviour of the composites was systematically investigated, and the related mechanism was discussed.

\section{Experimental Details}

$\mathrm{TiC}_{0.4}$ powder was synthesized via mechanical alloying (MA) using the production method described in Ref. 19. $\mathrm{TiC}_{0.4}$ (purity $99.6 \%$, size $180-200 \mathrm{~nm}$ ) and $\mathrm{Ti}_{3} \mathrm{SiC}_{2}$ (purity $99 \%$, size $30 \mu \mathrm{m}$ ) powders were used as raw materials. The $\mathrm{TiC}_{0.4}$ volume fraction was fixed at 10,20 , and 30 vol. $\%$ in the whole raw material, and the corresponding sintered samples were denoted as TC0 (10 vol.\% $\left.\mathrm{TiC}_{0.4}\right), \mathrm{TC} 1\left(20\right.$ vol. $\left.\% \mathrm{TiC}_{0.4}\right)$, and $\mathrm{TC} 2$ (30 vol.\% $\mathrm{TiC}_{0.4}$ ). These raw materials were well dispersed using the high-energy ball-milling method, and then the mixed powders were sintered using an SPS system (LABOX ${ }^{T M}-110$, Japan) at a sintering temperature of $1400^{\circ} \mathrm{C}$ and a holding time of $10 \mathrm{~min}$ under a pressure of $40 \mathrm{MPa}$ in a $30 \mathrm{~Pa}$ vacuum. The heating rate was set to $100^{\circ} \mathrm{C} / \mathrm{min}$.

The bulk density of the $\mathrm{TiC}_{0.4}-\mathrm{Ti}_{3} \mathrm{SiC}_{2}$ composite was measured by Archimedes' method. The theoretical density of TCO, TC1, and TC2 was $3.78,4.39$, and $4.64 \mathrm{~g} / \mathrm{cm}^{3}$, as calculated using the method described in Ref. 23. The hardness of the $\mathrm{Ti}_{3} \mathrm{SiC}_{2}$ matrix composite was measured by a Vicker's hardness instrument (FM-ARS9000, China) with a dwell time of $15 \mathrm{~s}$ at a load of $500 \mathrm{gf}$. Fracture toughness $\left(\mathrm{K}_{\mathrm{IC}}\right)$ was determined by the indentation method proposed in Ref. 24 with a load of $5000 \mathrm{~g}$ and a holding time of $15 \mathrm{~s}$. Friction and wear tests were carried out using a ball-on-disc system (TRB, Switzerland). A ball sliding on a linear reciprocating athletic flat specimen $(5 \mathrm{~mm} \times 15 \mathrm{~mm} \times 5 \mathrm{~mm})$ was adopted. The specimens were cut by electrical discharge method and the test surface was mechanically polished down to $2000 \# \mathrm{SiC}$ paper. The $\mathrm{Si}_{3} \mathrm{~N}_{4}$ balls were used as the friction counterparts with a diameter of $4 \mathrm{~mm}$ and a hardness of $15 \mathrm{GPa}$. Disc-specimens and $\mathrm{Si}_{3} \mathrm{~N}_{4}$ balls were cleaned by acetone solution before frictional wear tests. All tests were carried out under dry sliding conditions at room temperature $\left(25^{\circ} \mathrm{C}\right)$ in the air. The wear track diameter was typically $11-13 \mathrm{~mm}$. The tribological tests were performed at an applied load of $5 \mathrm{~N}$, at a sliding speed of $0.1 \mathrm{~m} / \mathrm{s}$, and a testing distance of $100 \mathrm{~m}$. The friction coefficient was 
continuously measured and automatically recorded by the computer system of the friction tester, while the wear rate was calculated using Archard's equation [25]:

$\mathrm{W}=V / \mathrm{P} \cdot \mathrm{L}$

where $V\left(\mathrm{~mm}^{3}\right)$ is the wear volume obtained by measuring the weight loss in a microbalance after ultrasonic cleaning and drying and the measured density, $P(\mathrm{~N})$ is the applied load, and $L(\mathrm{~m})$ is the total sliding distance.

\section{Results Ad Discussion}

The $\mathrm{TiC}_{0.4}-\mathrm{Ti}_{3} \mathrm{SiC}_{2}$ composite is composed of $\mathrm{Ti}_{3} \mathrm{SiC}_{2}$ (Fig. 1a, marked as $\mathrm{A}, \mathrm{D}, \mathrm{G}$, and $\mathrm{J}$ in Figs. $1 \mathrm{C}-\mathrm{f}$ ), $\mathrm{TiC}_{\mathrm{x}}$ (Fig. 1a, marked as B, E, and $\mathrm{H}$ in Figs. $1 \mathrm{C}-\mathrm{e}$ ) and $\mathrm{Ti}_{5} \mathrm{Si}_{3}$ (Fig. 1a, marked as $\mathrm{C}, \mathrm{F}$, and I in Figs. 1C-e). $\mathrm{Ti}_{3} \mathrm{SiC}_{2}, \mathrm{TiC}_{\mathrm{x}}$, and $\mathrm{Ti}_{5} \mathrm{Si}_{3}$ particles exhibit lamellar shape, equiaxed grains, and irregular shape, respectively. The relative content of each phase in the $\mathrm{TiC}_{0.4}-\mathrm{Ti}_{3} \mathrm{SiC}_{2}$ composite is semi-quantitatively calculated using the method described in Ref. 26. The relative content of $\mathrm{Ti}_{3} \mathrm{SiC}_{2}$ decreases, while the relative contents of $\mathrm{TiC}_{\mathrm{x}}$ and $\mathrm{Ti}_{5} \mathrm{Si}_{3}$ increase (Fig. $1 \mathrm{~b}$ ) with the increase of the $\mathrm{TiC}_{0.4}$ amount. The Ti-Si bonds in $\mathrm{Ti}_{3} \mathrm{SiC}_{2}$ are weaker than $\mathrm{Ti}-\mathrm{C}$ bonds [27], so that $\mathrm{TiC}_{0.4}$ can promote the $\mathrm{Ti}_{3} \mathrm{SiC}_{2}$ decomposition to form $\mathrm{TiC}_{\mathrm{x}}$ and $\mathrm{Ti}_{5} \mathrm{Si}_{3}$ in the environment of $\mathrm{C}$ vacancies generated by the $\mathrm{TiC}_{0.4}$ additions [28]. At the same time, $\mathrm{TiC}_{0.4}$ absorbs $\mathrm{C}$ atoms from $\mathrm{Ti}_{3} \mathrm{SiC}_{2}$ to form $\mathrm{TiC}_{x}$, which is more stable than $\mathrm{TiC}_{0.4}$, resulting in the small diffraction peak broadening of $\mathrm{TiC}_{\mathrm{x}}$, compared with that of $\mathrm{TiC}_{0.4}$ (Fig. 1a). $\mathrm{The}^{\mathrm{Ti}} \mathrm{SiC}_{2}$ decomposition and $\mathrm{TiC}_{\mathrm{x}}$ generation reactions can be described as follows [29]:

$\mathrm{Ti}_{3} \mathrm{SiC}_{2} \rightarrow \mathrm{TiC}_{x}+\mathrm{Si}$

$5 \mathrm{Ti}+3 \mathrm{Si}=\mathrm{Ti}_{5} \mathrm{Si}_{3}$

TiC $_{0.4}+C \rightarrow$ TiC $_{x}$

The $\mathrm{Ti}_{3} \mathrm{SiC}_{2}$ grain size decreases from 3.3-6.1 $\mu \mathrm{m}$ (mean of $5.2 \mu \mathrm{m}$ ) to 1.4-2.8 $\mu \mathrm{m}$ (mean of $2.1 \mu \mathrm{m}$ ) (Figs. 1c-e) because $\mathrm{TiC}_{\mathrm{x}}$ is prone to concentrate around the $\mathrm{Ti}_{3} \mathrm{SiC}_{2}$ grain boundaries, hindering the $\mathrm{Ti}_{3} \mathrm{SiC}_{2}$ grain growth during the sintering process (Figs. $1 \mathrm{c}-\mathrm{e}$ ). The porosity in the $\mathrm{TiC}_{0.4}-\mathrm{Ti}_{3} \mathrm{SiC}_{2}$ composite gradually decreases with the increase of the $\mathrm{TiC}_{0.4}$ amount (Figs. 1c-e). In addition, the fracture morphology of the $\mathrm{TiC}_{0.4}-\mathrm{Ti}_{3} \mathrm{SiC}_{2}$ composite includes transgranular and intergranular fractures (Figs. 1ce). The crack propagates at the $\mathrm{Ti}_{3} \mathrm{SiC}_{2}$ particles of $\mathrm{TC} 2$, indicating that the interfacial bonding between $\mathrm{Ti}_{3} \mathrm{SiC}_{2}$ and $\mathrm{TiC}_{\mathrm{x}}$ is stronger than the $\mathrm{Ti}_{3} \mathrm{SiC}_{2}$ fracture strength (see Fig. 1f). Thus, the interfacial bonding between $\mathrm{Ti}_{3} \mathrm{SiC}_{2}$ and $\mathrm{TiC}_{\mathrm{x}}$ is good. The good interfacial bonding between $\mathrm{Ti}_{3} \mathrm{SiC}_{2}$ and $\mathrm{TiC}_{\mathrm{x}}$ is attributed to the atomic diffusion of the elements. The reaction layer is about $65-80 \mu \mathrm{m}$ in the layered sintered $\mathrm{TiC}_{0.4}$ and $\mathrm{Ti}_{3} \mathrm{SiC}_{2}$ composite, indicating a good wettability between $\mathrm{TiC}_{0.4}$ and $\mathrm{Ti}_{3} \mathrm{SiC}_{2}$ (Fig. 2). The Si content in the reaction layer is higher than in the $\mathrm{Ti}_{3} \mathrm{SiC}_{2}$ region, while the $\mathrm{C}$ content is lower than in the $\mathrm{Ti}_{3} \mathrm{SiC}_{2}$ 
and $\mathrm{TiC}_{0.4}$ regions. According to the phase composition of the $\mathrm{TiC}_{0.4}-\mathrm{Ti}_{3} \mathrm{SiC}_{2}$ composite (Fig. $1 \mathrm{a}$ ), $\mathrm{Ti}_{5} \mathrm{Si}_{3}$ and $\mathrm{TiC}_{\mathrm{x}}$ are formed in the reaction layer. The $\mathrm{C}$ vacancies can improve the wettability between $\mathrm{TiC}_{0.4}$ and $\mathrm{Ti}_{3} \mathrm{SiC}_{2}$ by enhancing the atomic diffusion ability of the elements, yielding the formation of $\mathrm{TiC}_{\mathrm{x}}$ and $\mathrm{Ti}_{5} \mathrm{Si}_{3}$ by the $\mathrm{Ti}_{3} \mathrm{SiC}_{2}$ decomposition. This can change the interfacial structure between $\mathrm{TiC}_{0.4}$ and $\mathrm{Ti}_{3} \mathrm{SiC}_{2}$ and promote interfacial bonding, enhancing the mechanical and tribological properties of the composite $[21,22]$.

The bulk density, relative density, hardness, fracture toughness, friction coefficient, and wear rate of $\mathrm{TiC}_{0.4}-\mathrm{Ti}_{3} \mathrm{SiC}_{2}$ composites are in the range of $3.7-4.63 \mathrm{~g} / \mathrm{cm}^{3}, 98.1-99.7 \%, 4-14.87 \mathrm{GPa}, 3.6-5.45$ MPa $\cdot \mathrm{m}^{1 / 2}, 0.63-0.74$, and $(4.32-6.49) \times 10^{-7} \mathrm{~mm}^{3} \mathrm{~N}^{-1} \mathrm{~m}^{-1}$, respectively (Figs. 3a, b, and f). The indentations of hardness and fracture cover the whole phases of the $\mathrm{TiC}_{0.4}-\mathrm{Ti}_{3} \mathrm{SiC}_{2}$ composites at the optical microscope so that the values of hardness and fracture toughness of the $\mathrm{TiC}_{0.4}-\mathrm{Ti}_{3} \mathrm{SiC}_{2}$ composites measured by indentation method are accurate (Figs. $3 \mathrm{c}$ and d). The values of bulk density, relative density, hardness, and fracture toughness exhibit the same trend of a continuous increase with the $\mathrm{TiC}_{0.4}$ amount, while the wear rate exhibits a declining trend. The value of the friction coefficient remains stable initially and then increases. With a $30 \mathrm{vol} . \% \mathrm{TiC}_{0.4}$ addition, the bulk density, relative density, hardness and fracture toughness of the $\mathrm{TiC}_{0.4}-\mathrm{Ti}_{3} \mathrm{SiC}_{2}$ composites reach maximum values of $4.63 \mathrm{~g} / \mathrm{cm}^{3}, 99.7 \%$, $14.87 \mathrm{GPa}$, and $5.45 \mathrm{MPa} \cdot \mathrm{m}^{1 / 2}$, respectively, while the wear rate reaches a minimum value of $4.32 \times 10^{-7} \mathrm{~mm}^{3} \mathrm{~N}^{-1} \mathrm{~m}^{-1}$. With a $20 \mathrm{wt}$ \% $\mathrm{TiC}_{0.4}$ addition, the friction coefficient of the $\mathrm{TiC}_{0.4}-\mathrm{Ti}_{3} \mathrm{SiC}_{2}$ composites reaches a minimum value of 0.63 . The behaviour of bulk density, hardness, and fracture toughness values with the $\mathrm{TiC}_{0.4}$ amount originates from the contribution of three factors. Firstly, the relative contents of $\mathrm{TiC}_{\mathrm{x}}\left(4.46-4.86 \mathrm{~g} / \mathrm{cm}^{3}\right.$ and $\left.18-32 \mathrm{GPa}[20,30]\right)$ and $\mathrm{Ti}_{5} \mathrm{Si}_{3}\left(4.32 \mathrm{~g} / \mathrm{cm}^{3}\right.$ and $\left.9.5 \mathrm{GPa}\right)$ phases increase with the increase of the $\mathrm{TiC}_{0.4}$ amount, while the relative content of the $\mathrm{Ti}_{3} \mathrm{SiC}_{2}$ matrix $\left(4.53 \mathrm{~g} / \mathrm{cm}^{3}\right.$ and $4 \mathrm{GPa}$ ) decrease, yielding a higher bulk density and hardness of $\mathrm{TiC}_{0.4}-\mathrm{Ti}_{3} \mathrm{SiC}_{2}$ composites (Figs. 1a-b). Secondly, the $\mathrm{TiC}_{0.4}$ addition can improve the interfacial bonding of $\mathrm{Ti}_{3} \mathrm{SiC}_{2}$ and $\mathrm{TiC}_{\mathrm{x}}$ so that it is conducive to the stress transfer from the $\mathrm{Ti}_{3} \mathrm{SiC}_{2}$ matrix to $\mathrm{TiC}_{\mathrm{x}}$ at high pressure and impeding the grain boundary sliding, which increases the resistance of dislocation movement (Figs. 1c-f). It yields an improvement in density, hardness and fracture toughness of the $\mathrm{TiC}_{0.4}-\mathrm{Ti}_{3} \mathrm{SiC}_{2}$ composites.

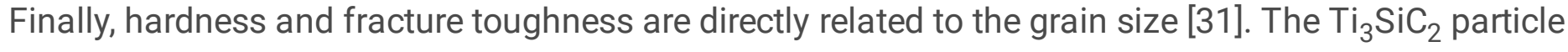
size decreases with increase with the increase of the $\mathrm{TiC}_{0.4}$ amount, causing an increase in the grain boundaries of $\mathrm{TiC}_{0.4}-\mathrm{Ti}_{3} \mathrm{SiC}_{2}$ composites and resulting in higher hardness and fracture toughness (Figs. 1c-e) $[32,33]$. Although the fracture toughness of the $\mathrm{TiC}_{0.4}-\mathrm{Ti}_{3} \mathrm{SiC}_{2}$ composites is close to the mean value reported in the previous studies $[7,14,30,34-39]$, the $\mathrm{TiC}_{0.4}-\mathrm{Ti}_{3} \mathrm{SiC}_{2}$ composites exhibit an unprecedentedly high hardness of $\sim 14.87 \mathrm{GPa}$ (Fig. 3e). $\mathrm{TiC}_{\mathrm{x}}$ particles can effectively pin the $\mathrm{Ti}_{3} \mathrm{SiC}_{2}$ matrix to prevent the $\mathrm{Ti}_{3} \mathrm{SiC}_{2}$ detaching during the friction process due to the high hardness and strong interfacial bonding between $\mathrm{TiC}_{\mathrm{x}}$ and $\mathrm{Ti}_{3} \mathrm{SiC}_{2}$ (Fig. 1) [14]. In addition, the decrease of grain size lowers the wear rate due to the mitigation of multiple risks caused by plastic deformation, fracture, 
fragmentation, and oxidation of grains [40]. The detached particles partly form a lubricating film on the friction surface of $\mathrm{TiC}_{0.4}-\mathrm{Ti}_{3} \mathrm{SiC}_{2}$ composite, while others yield wear debris, which is later removed [32]. As the $\mathrm{TiC}_{0.4}$ addition increases from 20 to $30 \mathrm{vol} \%$, the friction coefficient increases although the wear rate decreases, implying that the excessive $\mathrm{TiC}_{\mathrm{x}}$ particles destroy the continuity of the lubrication film formed by the $\mathrm{Ti}_{3} \mathrm{SiC}_{2}$ matrix (Fig. $4 \mathrm{~b}$-d). It is worth noting that $\mathrm{TiC}_{0.4}-\mathrm{Ti}_{3} \mathrm{SiC}_{2}$ composites show a wear rate as low as $4.32-6.49 \times 10^{-7} \mathrm{~mm}^{3} \mathrm{~N} \mathrm{~m}^{-1}$, which is much lower than the values reported for pure $\mathrm{Ti}_{3} \mathrm{SiC}_{2}$ and other $\mathrm{Ti}_{3} \mathrm{SiC}_{2}$-based ceramics $[14,37,41-46]$.

The relationship between friction coefficient and friction distance of the $\mathrm{TiC}_{0.4}-\mathrm{Ti}_{3} \mathrm{SiC}_{2}$ composites can be divided into two stages, i.e., initial friction and stable friction (Fig. 4a). The friction distance of the $\mathrm{TiC}_{0.4^{-}}$ $\mathrm{Ti}_{3} \mathrm{SiC}_{2}$ composites in the stable friction stage is from the end of the initial friction stage to the end of the friction process (Fig. 4a). The friction distance of TCO, TC1, and TC2 is about 4, 26, and $38 \mathrm{~m}$ in the initial friction stage. Detached particles gradually form the lubricating film on the friction surface of $\mathrm{TiC}_{0.4^{-}}$ $\mathrm{Ti}_{3} \mathrm{SiC}_{2}$ composites during the friction process in the initial friction stage [38]. Since the more lubricating film is formed than lost through the wear debris formation, the friction coefficient gradually increases and fluctuates significantly in the initial friction stage. As the friction distance increases, the formed lubricating film covers the complete friction surface of the $\mathrm{TiC}_{0.4}-\mathrm{Ti}_{3} \mathrm{SiC}_{2}$ composite, yielding the stage of stable friction. Consequently, the lubricating film production of $\mathrm{TiC}_{0.4}-\mathrm{Ti}_{3} \mathrm{SiC}_{2}$ composites is in dynamic balance with its loss during the friction process, and the friction coefficient curve becomes smooth [48]. The content of $\mathrm{TiC}_{\mathrm{x}}$ particles in the detached particles increases with the increase of the $\mathrm{TiC}_{0.4}$ amount, hampering the formation of the complete lubricating film on the friction surface of the $\mathrm{TiC}_{0.4}-\mathrm{Ti}_{3} \mathrm{SiC}_{2}$ composite so that the friction distance of the initial friction increases. The friction surface of the $\mathrm{TiC}_{0.4^{-}}$ $\mathrm{Ti}_{3} \mathrm{SiC}_{2}$ composites mainly exhibits abrasive debris (Figs. 4b-d), indicating that the wear mechanism of the $\mathrm{TiC}_{0.4}-\mathrm{Ti}_{3} \mathrm{SiC}_{2}$ composites is adhesive wear. The abrasive debris on the friction surface decreases with the increae of the $\mathrm{TiC}_{0.4}$ amount. The $\mathrm{C}$ content in the smooth regions $(\mathrm{L}, \mathrm{N}$, and $\mathrm{O}$ points in Figs. $4 \mathrm{~b}$ $\mathrm{d}$ and Table 1 ) is lower than in the abrasive areas ( $\mathrm{K}$ and $\mathrm{M}$ points in Figs. $4 \mathrm{~b}-\mathrm{c}$ and Table 1 ), unlike the 0 content. In addition, the $\mathrm{O}$ content in the smooth regions decreases with the increae of the $\mathrm{TiC}_{0.4}$ amount, while the $\mathrm{C}$ content increases in the smooth regions. Conclusively, the formation of abrasive debris is caused by the shedding of the lubricating film, which is inhibited by the $\mathrm{TiC}_{0.4}$ amount, decreasing the wear rate. 
Table 1

The EDS elemental analysis (wt.\%) of the regions marked in Figs. 4b-

d

\begin{tabular}{|llllll|}
\hline EDS measured points & $\mathrm{Ti}$ & $\mathrm{Si}$ & $\mathbf{0}$ & $\mathrm{Fe}$ & $\mathrm{C}$ \\
\hline $\mathrm{K}$ & 33.23 & 12.58 & 35.11 & 1.08 & 18 \\
$\mathrm{~L}$ & 37.34 & 14.15 & 26 & 1.23 & 21.28 \\
$\mathrm{M}$ & 32.78 & 14.34 & 24.29 & 0.85 & 25.74 \\
$\mathrm{~N}$ & 35.91 & 15.01 & 20 & 1.97 & 27.11 \\
\hline $\mathrm{O}$ & 31.06 & 13.33 & 22.11 & 1.14 & 32.36 \\
\hline
\end{tabular}

The $\mathrm{C}$ vacancies in $\mathrm{TiC}_{0.4}$ promote the $\mathrm{Ti}_{3} \mathrm{SiC}_{2}$ decomposition, and thus, the formation of $\mathrm{TiC}_{\mathrm{x}}$ and $\mathrm{Ti}_{5} \mathrm{Si}_{3}$ hard phases (Figs. 1a-b) and also improve the interfacial bonding between $\mathrm{Ti}_{3} \mathrm{SiC}_{2}$ and $\mathrm{TiC}_{\mathrm{x}}(\mathrm{Figs}$. $1 \mathrm{c}-\mathrm{f}$ and Fig. 2). In addition, the $\mathrm{TiC}_{0.4}$ addition causes the formation of the hard $\mathrm{TiC}_{\mathrm{x}}$ phase around the $\mathrm{Ti}_{3} \mathrm{SiC}_{2}$ grain boundaries, decreasing the $\mathrm{Ti}_{3} \mathrm{SiC}_{2}$ grain size (Figs. 1c-e). The synergistic effect of these factors improves the mechanical and tribological properties of the $\mathrm{TiC}_{0.4}-\mathrm{Ti}_{3} \mathrm{SiC}_{2}$ composites (Figs. 3). However, it affects the tribological properties mainly through the formation of the lubricating film on the surface of the $\mathrm{TiC}_{0.4}-\mathrm{Ti}_{3} \mathrm{SiC}_{2}$ composites. As the formation of the lubricating film is in a dynamic balance with its loss during the friction process, the lubricating film is formed on the entire friction surface of the $\mathrm{TiC}_{0.4}-\mathrm{Ti}_{3} \mathrm{SiC}_{2}$ composites, stabilizing the friction coefficient (Fig. 4 and Table 1). The lubricating film integrity is improved by the pinning effect of TiC particles, decreasing the friction coefficient and wear rate. Still, the pinning effect of $\mathrm{TiC}$ particles is limited by the continuity of the lubricating film. If $\mathrm{TiC}_{\mathrm{x}}$ particles in the $\mathrm{TiC}_{0.4}-\mathrm{Ti}_{3} \mathrm{SiC}_{2}$ composites are present in excess, the continuity of lubricating film will decrease although the pinning effect of TiC particles is improved, yielding an increase of friction coefficient (Fig. 3d, Fig. 4, and Table 1).

\section{Conclusions}

$\mathrm{TiC}_{0.4}-\mathrm{Ti}_{3} \mathrm{SiC}_{2}$ composites composed of $\mathrm{Ti}_{3} \mathrm{SiC}_{2}, \mathrm{Ti}_{5} \mathrm{Si}_{3}$, and $\mathrm{TiC}_{\mathrm{x}}$ were manufactured using SPS at $1400^{\circ} \mathrm{C}$ for $10 \mathrm{~min}$. The relative content of $\mathrm{Ti}_{3} \mathrm{SiC}_{2}$ decreased, while the relative contents of $\mathrm{TiC}_{\mathrm{x}}$ and $\mathrm{Ti}_{5} \mathrm{Si}_{3}$ increased with the increase of the $\mathrm{TiC}_{0.4}$ amount. $\mathrm{TiC}_{\mathrm{x}}$ was concentrated around the grain boundaries of $\mathrm{Ti}_{3} \mathrm{SiC}_{2}$. The $\mathrm{TiC}_{0.4}$ addition improved the mechanical and tribological properties of the $\mathrm{TiC}_{0.4}-\mathrm{Ti}_{3} \mathrm{SiC}_{2}$ composites due to the presence of $\mathrm{C}$ vacancies in $\mathrm{TiC}_{0.4}$. $\mathrm{The}^{\mathrm{Ti}} \mathrm{SiC}_{2}$ composite with 30 vol.\% $\mathrm{TiC}_{0.4}$ exhibited better comprehensive properties than other composites. The bulk density, relative density, hardness, fracture toughness, friction coefficient, and wear rate of the $30 \mathrm{vol}$. $\% \mathrm{TiC}_{0.4}-\mathrm{Ti}_{3} \mathrm{SiC}_{2}$ composite were $4.63 \mathrm{~g} / \mathrm{cm}^{3}, 99.7 \%, 14.87 \mathrm{GPa}, 5.45 \mathrm{MPa} \cdot \mathrm{m}^{1 / 2}, 0.74$, and $4.32 \times 10^{-7} \mathrm{~mm}^{3} \mathrm{~N}^{-1} \mathrm{~m}^{-1}$, respectively. 
This work provides a theoretical basis for studying other materials enhanced by the addition of nonstoichiometric compounds and broadens the application spectra of the $\mathrm{Ti}_{3} \mathrm{SiC}_{2}$ matrix composites under severe environments.

\section{Declarations}

\section{Acknowledgments}

This work was supported by the Key Program of Scientific Research of Higher Education of Hebei Province (Grant No. ZD2021099).

\section{References}

1. Radovic, M., Barsoum, M.M.W., Ganguly, A., Zhen, T., Finkel, P., Kalidindi, S.R., Lara-Curzio, E.: On the elastic properties and mechanical damping of $\mathrm{Ti}_{3} \mathrm{SiC}_{2}, \mathrm{Ti}_{3} \mathrm{GeC}_{2}, \mathrm{Ti}_{3} \mathrm{Si}_{0.5} \mathrm{Al}_{0.5} \mathrm{C}_{2}$ and $\mathrm{Ti}_{2} \mathrm{AlC}$ in the 300$1573 \mathrm{~K}$ temperature range. Acta Mater. 54, 2757-2767 (2006).

https://doi.org/10.1016/j.actamat.2006.02.019

2. Li, S.B., Xie, J.X., Zhao, J.Q., Zhang, L.T.: Mechanical properties and mechanism of damage tolerance for $\mathrm{Ti}_{3} \mathrm{SiC}_{2}$. Mater. Lett. 57, 119-123 (2002). https://doi.org/10.1016/S0167-577X(02)00716-4

3. Travaglini, J., Barsoum, M.B., Jovic, V., El-Raghy, T.: The corrosion behavior of $\mathrm{Ti}_{3} \mathrm{SiC}_{2}$ in common acids and dilute $\mathrm{NaOH}$. Corros. Sci. 45, 1313-1327 (2003)

4. Zhang, H.B., Zhou, Y.C., Bao, Y.W., Li, M.S.: Abnormal thermal shock behavior of $\mathrm{Ti}_{3} \mathrm{SiC}_{2}$ and $\mathrm{Ti}_{3} \mathrm{AlC}_{2}$ [J]. J. Mater. Res. 21, 2401-2407 (2006). https://doi.org/10.1557/jmr.2006.0289

5. Su, X.J., Bao, Y.W., Wang, D.T., Zhang, H.B., Xu, L.D., Grasso, S., Hu, C.F.: Thermal shock resistance of $\mathrm{Ti}_{3} \mathrm{SiC}_{2}$ ceramic under extremely rapid. J. Alloy. Compd. 886(15), 158985 (2021). https://doi.org/10.1016/S0167-577X(02)00716-4

6. Sarkar, S., Kumar, B.V., Basu, B.: Understanding the fretting wear of $\mathrm{Ti}_{3} \mathrm{SiC}_{2}$. J. Eur. Ceram. Soc. 26, 2441-2452 (2006). https://doi.org/10.1016/j.jeurceramsoc.2005.05.006

7. Yang, J., Gu, W., Pan, L.M., Song, K., Chen, X., Qiu, T.: Friction and wear properties of in situ $\left(\mathrm{TiB}_{2}+\right.$ $\mathrm{TiC}) / \mathrm{Ti}_{3} \mathrm{SiC}_{2}$ composites. Wear. 271, 2940-2946 (2011). https://doi.org/10.1016/j.wear.2011.06.017

8. Pasumarthi, V., Yao, C., Bakshi, S.R., Agarwal, A.: Reaction Synthesis of $\mathrm{Ti}_{3} \mathrm{SiC}_{2}$ Phase in Plasma Sprayed Coating. J. Alloy. Compd. 484, 113-117 (2009).

https://doi.org/10.1016/j.jallcom.2009.04.079

9. Mu, Y.C., Guo, J.F., Liang, B.Y., Wang, Q.S.: Rapid fabrication of the $\mathrm{Ti}_{3} \mathrm{SiC}_{2}$ bonded diamond composite by spark plasma sintering. Int. J. Refract Metal Hard Mater. 29, 397-400 (2011). https://doi.org/10.1016/j.jijmhm.2013.01.016

10. Huang, X.C., Feng, Y., Qian, G., Zhou, Z.J.: Arc ablation properties of $\mathrm{Ti}_{3} \mathrm{SiC}_{2}$ material. Ceram. Int. 45, 20297-20306 (2019). https://doi.org/10.1016/j.ceramint.2019.06.305 
11. Istomin, P., Istomina, E., Nadutkin, A., Grass, V.: Fabrication of $\mathrm{Ti}_{3} \mathrm{SiC}_{2} / \mathrm{SiC}$ multiport minichannel plates for high-temperature applications. J. Eur. Ceram. Soc. 39, 4602-4608 (2019). https://doi.org/10.1016/j.jeurceramsoc.2019.06.055

12. Zhu, Y.Y., Zhou, A.G., Ji, Y.Q., Jia, J., Wang, L.B., Wu, B., Zan, Q.F.: Tribological properties of $\mathrm{Ti}_{3} \mathrm{SiC}_{2}$ coupled with different counterfaces. Ceram. Int. 41(5), 6950-6955 (2015). https://doi.org/10.1016/j.ceramint.2015.01.150

13. Hu, C.F., Zhou, Y.C., B, Y.W., Wan, D.T.: Tribological Properties of Polycrystalline $\mathrm{Ti}_{3} \mathrm{SiC}_{2}$ and $\mathrm{Al}_{2} \mathrm{O}_{3}-$ Reinforced $\mathrm{Ti}_{3} \mathrm{SiC}_{2}$ Composites. J. Am. Ceram. Soc. 89, 3456-3461 (2006). https://doi.org/10.1111/j.1551-2916.2006.01253.x

14. Islak, B.Y., Ayas, E.: Evaluation of properties of spark plasma sintered $\mathrm{Ti}_{3} \mathrm{SiC}_{2}$ and $\mathrm{Ti}_{3} \mathrm{SiC}_{2} / \mathrm{SiC}$ composites. Ceram. Int. 45(9), 12297-12306 (2019). https://doi.org/10.1016/j.ceramint.2019.03.144

15. Magnus, C., Cooper, D., Ma, L., Rainforth, W.M.: Microstructures and intrinsic lubricity of in situ $\mathrm{Ti}_{3} \mathrm{SiC}_{2}-\mathrm{TiSi}_{2}-\mathrm{TiC}$ MAX phase composite fabricated by reactive spark plasma sintering (SPS). Wear 2020; 448-449. https://doi.org/10.1016/j.wear.2019.203169

16. Lv, Y.N., Gao, W.M.: Crystal structural and diffusion property in titanium carbides: A molecular dynamics study. Mod. Phys. Lett. B. 30(26), 1650334 (2016). https://doi.org/10.1142/S0217984916503346

17. Tang, X.C., Salehin, R., Thompson, G.B., Weinberger, C.R.: Statistical study of vacancy diffusion in TiC and TaC. Physical Review Materials. 4(9), 093602 (2020). https://doi.org/10.1103/PhysRevMaterials.4.093602

18. Zhang, Z.C., Geng, C.J., Ke, Y.J., Li, C., Jiao, X.C., Zhao, Y.C., Tang, H., Wang, M.Z.: Processing and mechanical properties of nonstoichiometric $\mathrm{TiC}_{\mathrm{x}}(0.3 \leq \mathrm{x} \leq 0.5)$. Ceram. Int. 44(15), 18996-19001 (2018). https://doi.org/10.1016/j.ceramint.2018.07.141

19. Vasanthakumar, K., Bakshi, S.R.: Effect of C/Ti ratio on densification, microstructure and mechanical properties of $\mathrm{TiC}_{\mathrm{x}}$ prepared by reactive spark plasma sintering. Ceram. Int. 44(1), 484-494 (2018). https://doi.org/10.1016/j.ceramint.2017.09.202

20. Han, J.H., Hwang, S.S., Lee, D.Y., Park, S.W.: Synthesis and mechanical properties of $\mathrm{Ti}_{3} \mathrm{AlC}_{2}$ by hot pressing $\mathrm{TiC}_{\mathrm{x}} /$ Al powder mixture. J. Eur. Ceram. Soc. 28, 979-988 (2008). https://doi.org/10.1016/j.jeurceramsoc.2007.09.015

21. Shu, S.L., Lu, J.B., Feng, Q., Xuan, Q.Q., Jiang, Q.C.: High volume fraction $\mathrm{TiC}_{\mathrm{x}} / \mathrm{Al}$ composites with good comprehensive performance fabricated by combustion synthesis and hot press consolidation[J]. Materials Science \& Engineering A. 528(4-5), 1931-1936 (2011). https://doi.org/10.1016/j.msea.2010.11.052

22. Y, L.G.Y., Wen, X.C., Gao, H., Wang, Z., Guo, Z.C.: Synthesis of Cu-based $\mathrm{TiC}_{\mathrm{x}}$ composites via in-situ reaction between $\mathrm{Cu}_{\mathrm{x}}$ Ti melt and dissolvable solid carbon. Powder Technol. 362, 375-385 (2020). https://doi.org/10.1016/j.powtec.2019.11.122 
23. Rahmani, K., Majzoobi, G., Compos, J.: The effect of particle size on microstructure, relative density

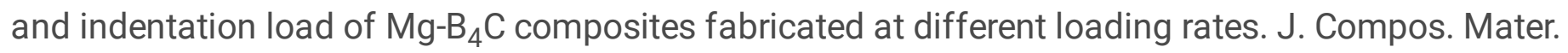
54(17), 1-15 (2020). https://doi.org/10.1177/0021998319896009

24. Xun, S., Wang, M.Z., Qiao, L., Bing, J.L., Zou, Q., Zhao, Y.C.: Enhancing the sintering ability of $\mathrm{TiN}_{\mathrm{x}}$ by introduction of nitrogen vacancy defects. Ceram. Int. 41(8), 9514-9520 (2015). https://doi.org/10.1016/j.ceramint.2015.04.009

25. Singh, J., Wani, M.F.: Fretting wear of spark plasma sintered $\mathrm{Ti}_{3} \mathrm{SiC}_{2} / \mathrm{GNP}$ ceramic composite against $\mathrm{Si}_{3} \mathrm{~N}_{4}$. Ceram. Int. 47(4), 5648-5655 (2020). https://doi.org/10.1016/j.ceramint.2020.10.150

26. Talero, R., Trusilewicz, L., Delgado, A., Pedrajas, C., Lannegrand, R., Rahhal, V., Mejía, R., Delvastoe, S., Ramírezf, F.A.: Comparative and semi-quantitative XRD analysis of Friedel's salt originating from pozzolan and Portland cement. Constr. Build. Mater. 25, 2370-2380 (2011).

https://doi.org/10.1016/j.conbuildmat.2010.11.037

27. Pang, W.K., Low, I.M.: Understanding and improving the thermal stability of layered ternary carbides in ceramic matrix composites. Advances in ceramic matrix composites 2014; 340-368. https://doi.org/10.1533/9780857098825.2.340

28. Son, Q., Zhang, P., Zhuang, J., Ning, X.J.: Migrating and clustering of He atoms in $\mathrm{Ti}_{3} \mathrm{SiC}_{2}$ : Firstprinciples calculations. Comput. Mater. Sci. 137, 327-331 (2017). https://doi.org/10.1016/j.commatsci.2017.06.004

29. Gao, N.F.: Y.Miyamoto and D.Zhang. On physical and thermochemical properties of high-purity $\mathrm{Ti}_{3} \mathrm{SiC}_{2}$. Mater. Lett. 55(1), 61-66 (2002). https://doi.org/10.1016/S0167-577X(01)00620-6

30. Liu, X.L., Zhang, H.B., Yu, L.P., Kang, J.G., He, Y.H.: Characterisation of solar-synthesised $\mathrm{TiC}_{\mathrm{x}}(\mathrm{x}=0.50$, $0.625,0.75,0.85,0.90$ and 1.0$)$ by $X$-ray diffraction, density and Vickers microhardness. Mater. Chem. Phys. 77, 711-718 (2002). https://doi.org/77:711-718 . 10.1016/S0254-0584(02)00131-1

31. Amiri, S.H., Kakroudi, M.G., Rabizadeh, T., Asl, M.S.: Characterization of hot-pressed $\mathrm{Ti}_{3} \mathrm{SiC}_{2}-\mathrm{SiC}$ composites. International Journal of Refractory Metals and Hard Materials. 90, 105232 (2020). https://doi.org/10.1016/j.ijrmhm.2020.105232

32. Zhu, Y.B., Chai, J.L., Shen, T.L., Wang, Z.G.: Mechanical and Friction Properties of Al2O3-ZrO2-TiC Composite with Varying TiC Contents Fabricated by Spark Plasma Sintering. Original Research Article. 52, 767-775 (2021). https://doi.org/10.1007/s11661-020-06122-3

33. Hwang, S.S., Lee, S.C., Han, J.H., Lee, D.Y., Park, S.W.: Machinability of $\mathrm{Ti}_{3} \mathrm{SiC}_{2}$ with layered structure synthesized by hot pressing mixture of $\mathrm{TiC}_{\mathrm{x}}$ and Si powder. J. Eur. Ceram. Soc. 32, 3493-3500 (2012). https://doi.org/10.1016/j.jeurceramsoc.2012.04.021

34. He, G.Q., Guo, R.X., Lin, M.S., Yang, Y., Wang, L.S., Q, Y.H., Zuo, J., Xu, J.J., Liu, C.S.: Microstructure and mechanical properties of short-carbon-fiber $/ \mathrm{Ti}_{3} \mathrm{SiC}_{2}$ composites. Journal of Advanced Ceramics. 9(6), 0-0 (2020). https://doi.org/10.1007/s40145-020-0408-3 
35. Wang, H.J., Jin, Z.H., Miyamoto, Y.: Effect of $\mathrm{Al}_{2} \mathrm{O}_{3}$ on mechanical properties of $\mathrm{Ti}_{3} \mathrm{SiC}_{2} / \mathrm{Al}_{2} \mathrm{O}_{3}$ composite. Ceram. Int. 28, 931-934 (2002). https://doi.org/10.1016/S0272-8842(02)00076-7

36. Zhang, J.F., Wang, L.J., Jiang, W., Chen, L.D.: Effect of TiC content on the microstructure and properties of $\mathrm{Ti}_{3} \mathrm{SiC}_{2}-\mathrm{TiC}$ composites in situ fabricated by spark plasma sintering. Materials Science and Engineering: A. 484, 137-143 (2008). https://doi.org/10.1016/j.msea.2007.12.004

37. Pan, W., Shi, S.L.: Toughening of $\mathrm{Ti}_{3} \mathrm{SiC}_{2}$ with 3Y-TZP addition by spark plasma sintering. J. Eur. Ceram. Soc. 27, 413-417 (2007). https://doi.org/10.1016/j.jeurceramsoc.2006.05.072

38. Islak, B.Y., Candar, D.G.: Synthesis and properties of $\mathrm{TiB}_{2} / \mathrm{Ti}_{3} \mathrm{SiC}_{2}$ composites. Ceram. Int. 47(1), 1439-1446 (2020). https://doi.org/10.1016/j.ceramint.2020.09.098

39. Amiria, S.H., Kakroudia, M.G., Rabizadeha, T., Asl, M.S.: Characterization of hot-pressed $\mathrm{Ti}_{3} \mathrm{SiC}_{2}-\mathrm{SiC}$ composites. Int. J. Refract Metal Hard Mater. 90, 105232 (2020). https://doi.org/10.1016/j.ijrmhm.2020.105232

40. Wang, H.B., Gee, M., Qiu, Q.F., Zhang, H.N., Liu, X.M., Nie, H.B., Song, X.Y., Nie, Z.R.: Grain size effect on wear resistance of WC-Co cemented carbides under different tribological conditions. Journal of Materials Science \& Technology. 35(11), 2435-2446 (2019). https://doi.org/10.1016/j.jmst.2019.07.016

41. Zhua, Y.Y., Zhou, A.G., Ji, Y.Q., Jia, J., Wang, L.B., Wu, B., Zan, Q.F.: Tribological properties of $\mathrm{Ti}_{3} \mathrm{SiC}_{2}$ coupled with different counterfaces. Ceram. Int. 41(5), 6950-6955 (2015). https://doi.org/10.1016/j.ceramint.2015.01.150

42. Yang, J., Gu, W., Pan, L.M., Song, K., Chen, X., Qiu, T.: Friction and wear properties of in situ $\left(\mathrm{TiB}_{2}+\right.$ $\mathrm{TiC}) / \mathrm{Ti}_{3} \mathrm{SiC}_{2}$ composites. Wear. 271(11), 2940-2946 (2011). https://doi.org/10.1016/j.wear.2011.06.017

43. Hu, C.F., Zhou, Y.C., Bao, Y.W., Wan, D.T.: Tribological Properties of Polycrystalline $\mathrm{Ti}_{3} \mathrm{SiC}_{2}$ and $\mathrm{Al}_{2} \mathrm{O}_{3}-$ Reinforced $\mathrm{Ti}_{3} \mathrm{SiC}_{2}$ Composites. J. Am. Ceram. Soc. 89(11), 3456-3461 (2010). https://doi.org/10.1111/j.1551-2916.2006.01253.x

44. Singh, J., Wani, M.F.: Fretting wear of spark plasma sintered $\mathrm{Ti}_{3} \mathrm{SiC}_{2} / \mathrm{GNP}$ ceramic composite against $\mathrm{Si}_{3} \mathrm{~N}_{4}$ - ScienceDirect. Ceram. Int. 47(4), 5648-5655 (2020). https://doi.org/10.1016/j.ceramint.2020.10.150

45. Zhai, H.X., Huang, Z.Y.: M.X. A Tribological behaviors of bulk $\mathrm{Ti}_{3} \mathrm{SiC}_{2}$ and influences of TiC impurities. Materials Science and Engineering: A. 435-436, 360-370 (2006). https://doi.org/10.1016/j.msea.2006.07.056

46. Shi, X.L., Wang, M., Xu, Z.S., Zhai, W.Z., Zhang, Q.X.: Tribological behavior of $\mathrm{Ti}_{3} \mathrm{SiC}_{2} /(\mathrm{WC}-10 \mathrm{Co})$ composites prepared by spark plasma sintering. Materials \& Design 2013. https://doi.org/10.1016/j.matdes.2012.08.069

47. Yin, Z.B., Yuan, J.T., Huang, C.Z., Wang, Z.H., Huang, L., Cheng, Y.: Friction and wear behaviors of $\mathrm{Al}_{2} \mathrm{O}_{3} / \mathrm{TiC}$ micro-nano-composite ceramic sliding against metals and hard materials. Ceram. Int. 42(1), 1982-1989 (2016). https://doi.org/10.1016/j.ceramint.2015.10.001 
48. Kumar, P., Srivastava, V.K.: Reciprocating sliding tribology of ceramic fiber composites with variation of laminate orientation and surface conformity. Ceram. Int. 44(5), 5365-5370 (2018). https://doi.org/10.1016/j.ceramint.2017.12.160

\section{Figures}
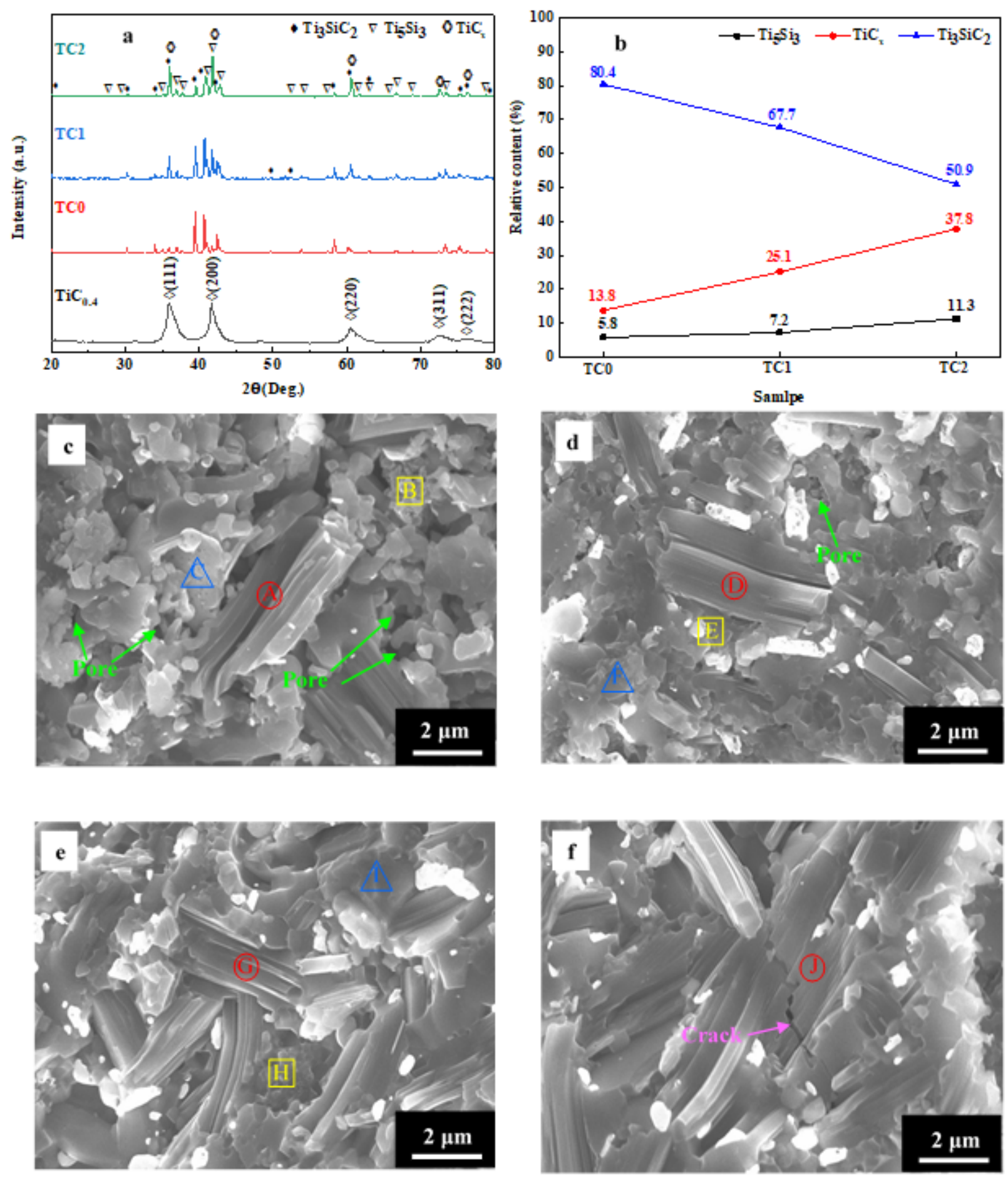

Figure 1 
(a) XRD patterns of $\mathrm{TiC}_{0.4}$ and the $\mathrm{TiC}_{0.4}-\mathrm{Ti}_{3} \mathrm{SiC}_{2}$ composites; (b) relative content of each phase in the $\mathrm{TiC}_{0.4}-\mathrm{Ti}_{3} \mathrm{SiC}_{2}$ composites; FESEM micrographs of the cross-sectional microstructures of the $\mathrm{TiC}_{0.4^{-}}$ $\mathrm{Ti}_{3} \mathrm{SiC}_{2}$ composites: (c) 10 vol.\% $\mathrm{TiC}_{0.4}-\mathrm{Ti}_{3} \mathrm{SiC}_{2}$, (d) 20 vol.\% $\mathrm{TiC}_{0.4^{-}}-\mathrm{Ti}_{3} \mathrm{SiC}_{2}$, and (e) 30 vol.\% $\mathrm{TiC}_{0.4^{-}}$ $\mathrm{Ti}_{3} \mathrm{SiC}_{2}$; (f) Crack propagation in the 30 vol.\% $\mathrm{TiC}_{0.4}-\mathrm{Ti}_{3} \mathrm{SiC}_{2}$ composite.
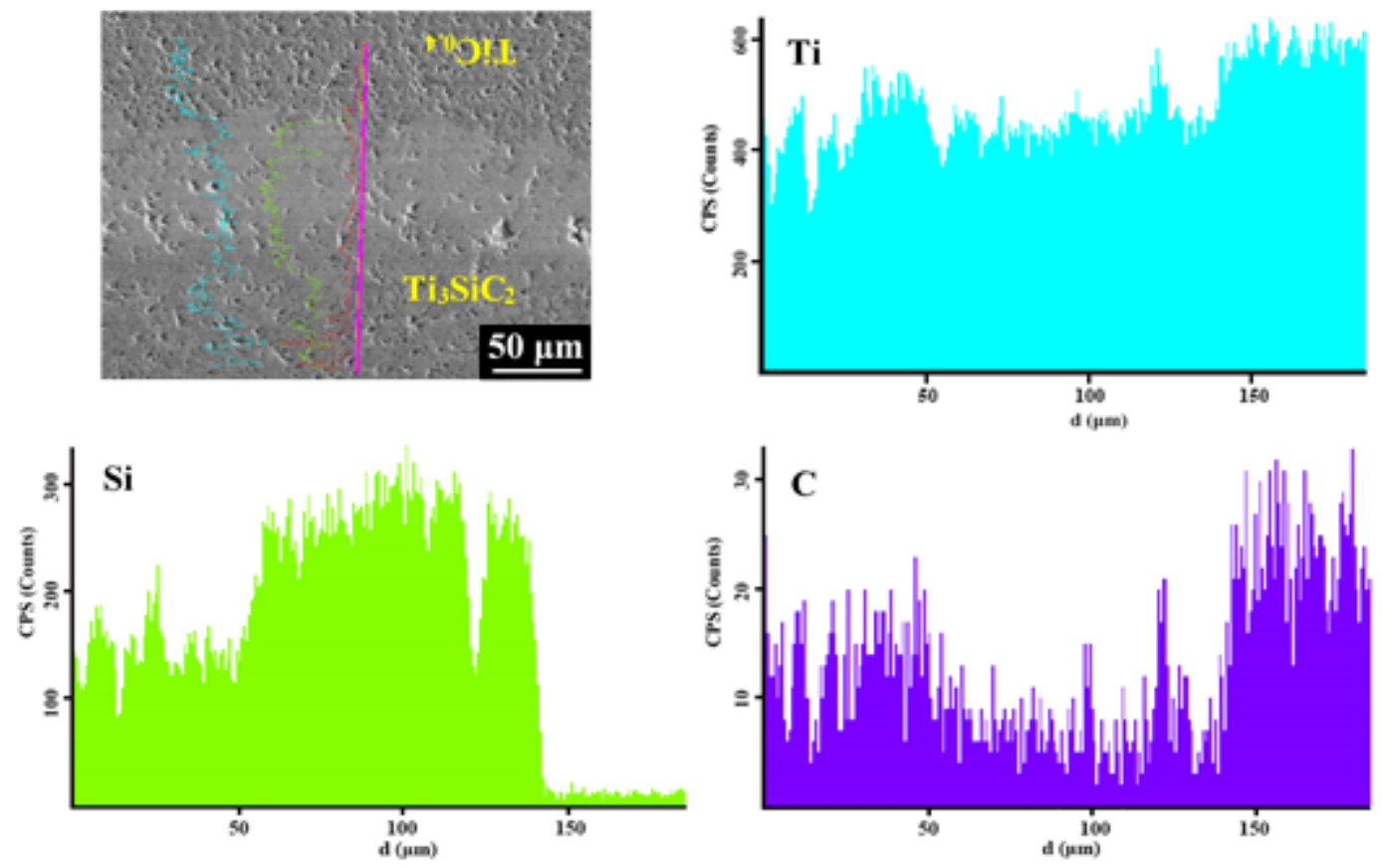

Figure 2

FESEM micrograph and the EDS line-scan analysis of the layered interface between $\mathrm{TiC}_{0.4}$ and $\mathrm{Ti}_{3} \mathrm{SiC}_{2}$ sintered at $1400^{\circ} \mathrm{C}$. 

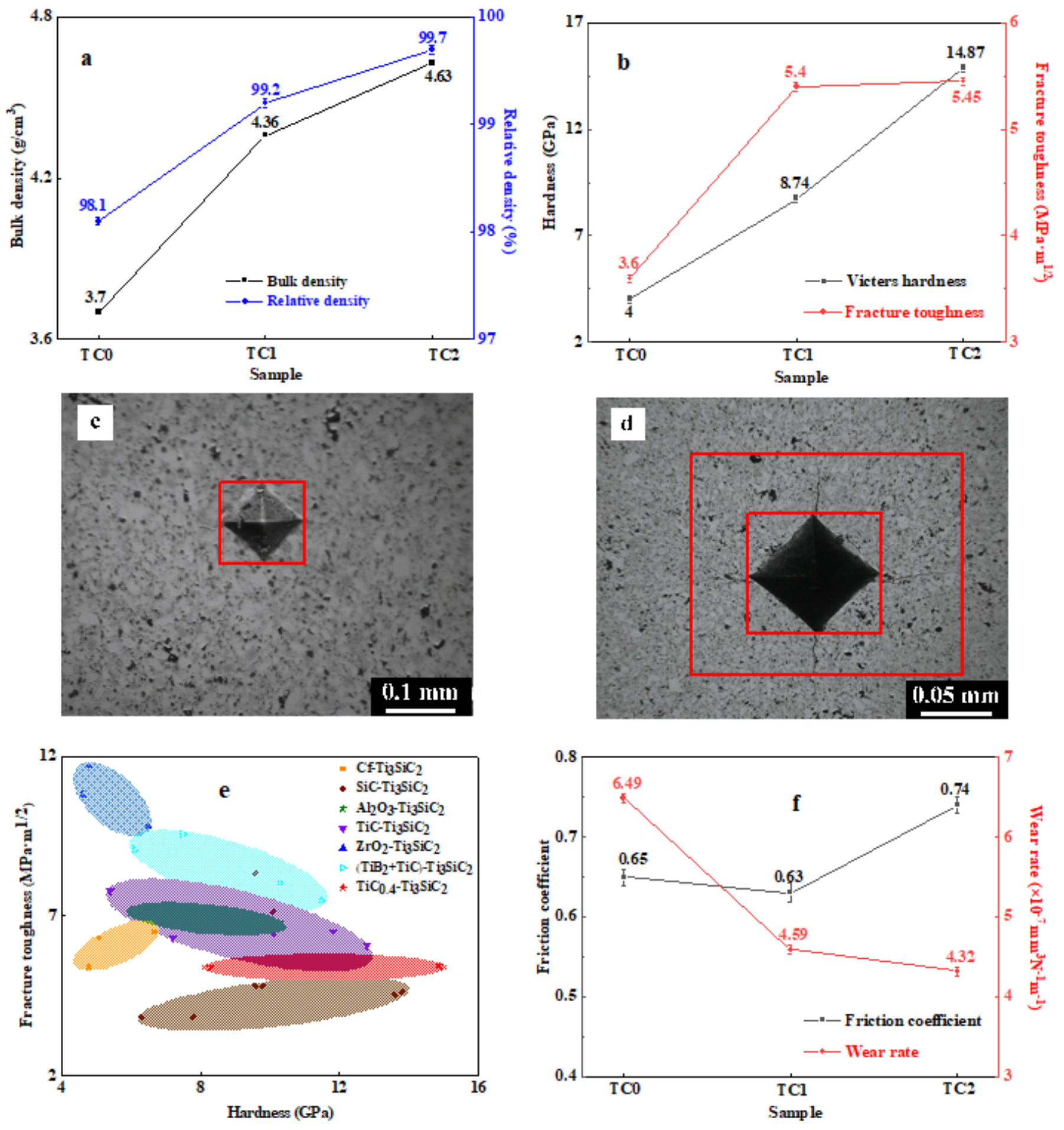

\section{Figure 3}

Mechanical and tribological properties of the $\mathrm{TiC}_{0.4}-\mathrm{Ti}_{3} \mathrm{SiC}_{2}$ composites. (a) density, (b) hardness and fracture toughness, (c) an optical microgragh of the Vickers indentation at load of $500 \mathrm{gf}$, (d) an optical microgragh of the Fractures indentation at a load of $5000 \mathrm{gf}$, (e) friction coefficient and wear rate; ( $\mathrm{f}$ ) the comparison of the hardness and fracture toughness values between the $\mathrm{TiC}_{0.4}-\mathrm{Ti}_{3} \mathrm{SiC}_{2}$ composites and other $\mathrm{Ti}_{3} \mathrm{SiC}_{2}$ matrix composites reported in the literature. 

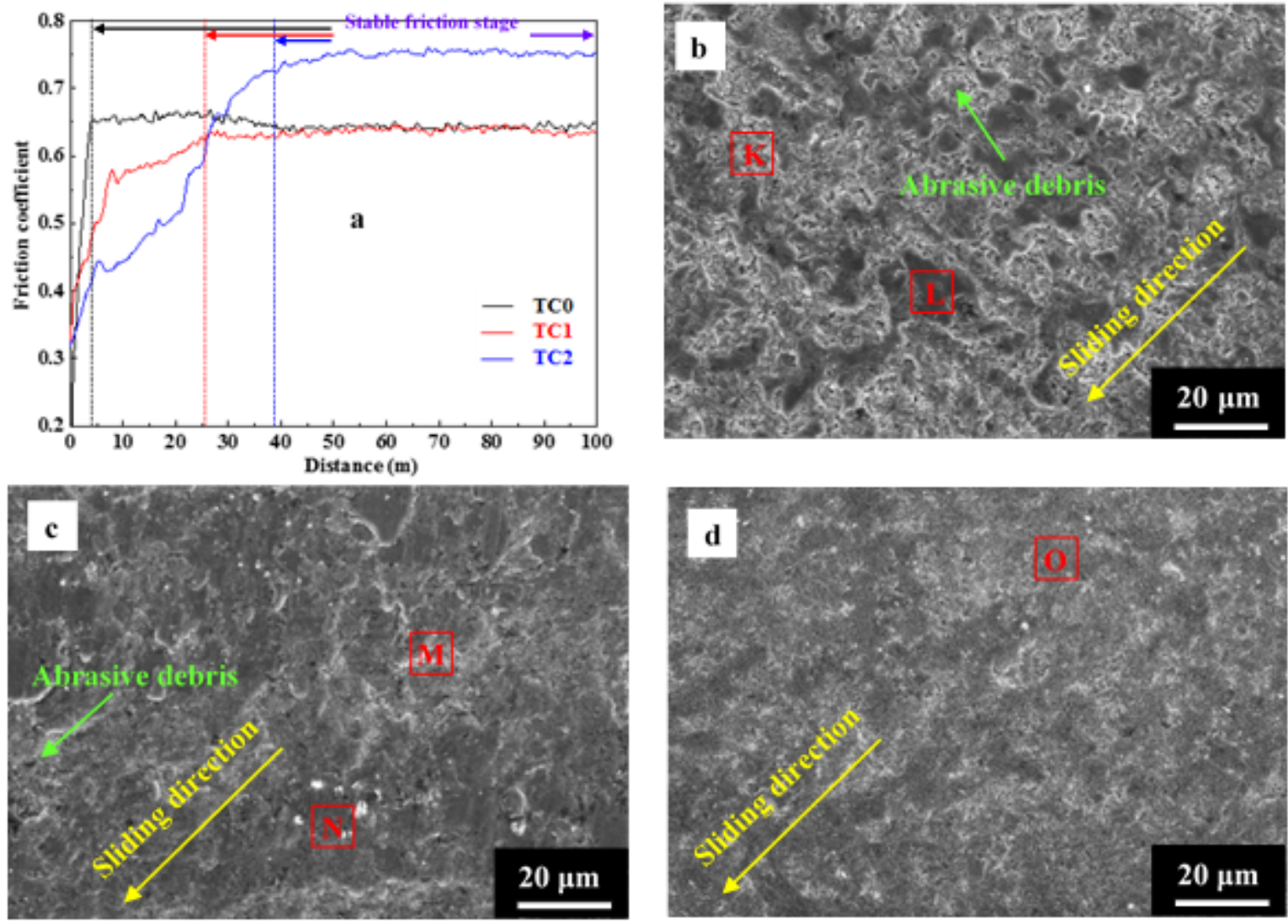

\section{Figure 4}

Tribological properties of the $\mathrm{TiC}_{0.4}-\mathrm{Ti}_{3} \mathrm{SiC}_{2}$ composites. (a) the relationship of friction coefficient and friction distance; FESEM micrographs of the friction surface of (b) TC0, (c) TC1 and (d) TC2. 